\title{
Assessment of Effect of Foliar Spray of Zinc Sulphate on Fruit Quality of Tomato under Polyhouse
}

\author{
Vimal Nagar $^{1 *}$, Susheel Kumar ${ }^{2}$, Upendar Kumar Bagri ${ }^{1}$, \\ Raja Ram Bunker ${ }^{1}$ and Himani Rana ${ }^{2}$ \\ ${ }^{1}$ Department of Horticulture, College of Agriculture, S.K.R.A.U. Bikaner-334006, \\ Rajasthan, India \\ ${ }^{2}$ Dev Bhoomi Group of Institutions, Dehradun, Uttrakhand, India \\ *Corresponding author
}

Keywords

Tomato, Polyhouse, Zinc sulphate, Foliar spray

Article Info

Accepted:

20 January 2021

Available Online:

10 February 2021
The experiment was carried out on tomato plants in a Polyhouse to see the effect of foliar spray of five levels of zinc sulphate $(0,50,100,150,200$ ppm) and number of sprays (first, second and third).15 treatment combinations were replicated three times in the Factorial Complete Randomized Design having bed size of $10 \mathrm{~m} \times 1 \mathrm{~m}$ with a row to row distance of $45 \mathrm{~cm}$ and plant to plant distance $60 \mathrm{~cm}$. The first, second and third spray of zinc sulphate was done 20,40 and 60 days after transplanting respectively. The increasing levels of zinc sulphate and number of sprays significantly increased the total soluble solid, ascorbic acid, and total sugar.

\section{Introduction}

Tomato (Solanum lycopersicum L.) comes under family Solanaceae, is said to be native of Tropical America (Thomson and Kelly, 1957). From tropical America it spread over other parts of the world in the $16^{\text {th }}$ century and became popular in India within last five decades. Tomato occupies an important place among vegetable crops and is grown in almost all parts of India under different agro-climatic conditions. It is one of the most important and remunerative vegetable crops in India.
In India, major tomato producing states are Bihar, Karnataka, Uttar Pradesh, Orissa, Andhra Pradesh, Maharashtra, Madhya Pradesh and West Bengal. In India, total production of tomato is approximately 18.74 million tonnes from an area about 0.88 million hectares with an average productivity of 16.1 metric tonnes per hectare (Anonymous, 2015). Rajasthan contributes about 7.52 million tonnes productions with an area of 0.16 million hectares and productivity of 4.5 metric tonnes per hectare. The major tomato growing districts of Rajasthan are Jaipur, Alwar, Tonk, 
Kota, and Bundi. Vegetables are an important part in balanced human diet along with fruits and milk. Besides the nutritive value, vegetables are capable of producing greater yields than any cereal crop which necessarily help in improving nutritional status of people and economic status of farmers. Further, vegetables are the cheapest and easily available source of the natural protective foods. In this context the tomato crop has its own importance as it can serve both the purposes that are of vegetables and fruits. It is an important source of minerals, vitamins and organic acids. Its richness in vitamins A, B and $\mathrm{C}$ make it unique among the vegetables.

Tomato fruits are consumed in many ways, cooked alone as well as mixed with other vegetables like potato, cauliflower, cabbage, brinjal etc. Its ripe fruits are consumed as raw or used into soups, pickles, ketchup, sauces etc. The pulp and juice of fruits are digestible and are mild aperients, a promoter of gastric, secretion and blood purifier.

To meet out the demand of increasing population, higher yield in all sort of agricultural produce is required; also the idea of quality cannot be overlooked. The higher yield combined with good quality of produce is the demand of the modern day. The aim of the agricultural scientists engaged in researches in fruits and vegetables is to explore the means and methods for high yields along with good quality.

Micronutrients usually required in minute quantities nevertheless are vital to the growth of plants (Benepal, 1967). Copper, manganese, zinc and iron are chiefly concerned with the oxidationreduction reaction (Wallace, 1957).

The micronutrients improve the chemical composition of fruits and general conditions of plant are known to act as catalyst in promoting organic reactions taking place in plants (Ranganathan and Perumal, 1995).

The method of application of micronutrients is of great importance considering their best utilization by plants. Foliar application is one of the efficient ways of application of micronutrients and is based on the fact that plants are capable of absorbing soluble compounds and gases through leaves (Kannan, 1990), nutrients applied will be absorbed and exported from point of application (leaf) to the point of utilization (usually growing tissues).

Applied nutrients are extensively fixed by cuticle at the point of application (Ferrandon and Chamel, 1988), at the same time it is more suitable owing to (i) convenience of application, (ii) requirement of small quantity, (iii) quick correction of deficiency and (iv) avoidance of fixation of the micronutrients in soil.

One of the important ways to increase quantity and quality of produce is through use of improved high yielding varieties. The high yielding varieties require higher dose of NPK fertilizer for their higher yield. With the requirement of major nutrients, a similar corresponding increase of minor elements like zinc, manganese, iron, molybdenum, boron ( $\mathrm{Zn}, \mathrm{Mn}, \mathrm{Fe}, \mathrm{Mo}, \mathrm{B})$ is also expected. These elements are called trace or minor elements of micronutrients. They play an important role as that of major nutrients. With the wide spread of high yielding and fertilizers responsive varieties, the stress on the soil micronutrient reserves has become severe. Consequently, zinc deficiency in particular, has become quite significant. Next to zinc deficiency, manganese and iron may prove to be limiting in agriculture production in near future. Instances of yield reduction on account of micronutrient deficiencies call for a thorough understanding of the various aspects of this group of elements. 
Zinc like other trace elements is known to be present in plant body long before its essentiality was proved. Zinc act as a catalyst and regulator in plant nutrition and plays an important role in oxidation-reduction. It is known to be related to the formation of chlorophyll. It has been observed that the development of green colour is associated with an increase in the zinc content of leaf. It is considered indispensable for the growth of all living organisms and its deficiency causes abnormalities in growth. Micronutrients are vitally connected with chlorophyll formation and act as an integral part of enzyme system and oxidation-reduction agent in biological system. Zinc deficiency in tomato has been reported to cause serious reduction in yield and quality.

India, being a vast country with diverse and extreme agro-climatic conditions, the protected vegetable cultivation technology can be utilized for the year round production of high value quality vegetable crops, with high yield. By protected cultivation, high water and nutrient use efficiencies can be achieved. Increasing photosynthetic efficiency and reduction in transpiratory losses are added advantages of protected cultivation, both these are of vital role for healthy and luxuriant growth of crop plant. This technology is highly suitable for farmers in urban areas of the country, especially in Northern plains of India. But protected cultivation requires careful planning and attention including selection of crops, varieties, suitable production technology like spacing, time of planting, water and nutrient management and plant protection measures to produce economic yield of better quality.

\section{Materials and Methods}

The experiment was laid out at Horticulture Research Farm, College of Agriculture, Swami Keshwanand Rajasthan Agricultural
University, Beechwal, Bikaner from December, 2016 to June, 2017. The experiment was laid out in Factorial Complete Randomized Design (F-CRD) with three replications. The treatments were randomized by using Fisher's random number table (Fisher, 1950). Tomato variety used in experiment was Arka Rakshak, procured from ICAR-IIHR, Bengaluru (Karnataka). Paired row planting system was followed for raising the crop under poly house. Zinc Sulphate (Zinc Sulphate heptahydrate) of concentration $(0,50,100,150,200 \mathrm{ppm})$ was applied as foliar spray at 20, 40 and 60 Days after transplanting. The experiment was comprised of 15 treatments and total plants under study were 1350 . The treatments with their symbols are given in the table 1 .

The detail of different operations followed for raising the experimental crop is given in table 2.

Data were collected on quality attributes i.e. Total Soluble Solids (\%), Moisture Content in Fruits (\%), Total Sugar (\%), and Ascorbic Acid (Mg $100 \mathrm{~g}^{-1}$ Pulp). Collected data were statistically analyzed as per procedure described by Panse and Sukhatme (1985). The critical difference were calculated to assess the significance of treatment means wherever, the "F" test was found significant at 5 per cent and 1 per cent level of significance. The analysis of variance for all the data discussed has been given in the respective appendices at the end.

\section{Results and Discussion}

\section{Quality attributes}

\section{Total soluble solids ( ${ }^{0}$ Brix)}

Total soluble solids were significantly influenced by different levels of zinc sulphate. Maximum total soluble solids were observed 
in $\mathrm{Zn}_{4}\left(5.66{ }^{0} \mathrm{Brix}\right)$ followed by $\mathrm{Zn}_{3}(5.54$ ${ }^{0}$ Brix $), \mathrm{Zn}_{2}\left(5.18{ }^{0} \mathrm{Brix}\right), \mathrm{Zn}_{1}\left(4.74{ }^{0} \mathrm{Brix}\right)$ and $\mathrm{Zn}_{0}\left(4.17{ }^{0}\right.$ Brix) but $\mathrm{Zn}_{4}\left(\mathrm{ZnSo}_{4} 200 \mathrm{ppm}\right)$ was statistically at par with $\mathrm{Zn}_{3}\left(\mathrm{ZnSo}_{4} 150 \mathrm{ppm}\right)$. Maximum total soluble solids $\left(5.81{ }^{\circ}\right.$ Brix) were observed in three sprays (at 20, 40 and 60 DAT). Whereas, minimum total soluble solids $\left(4.25{ }^{0}\right.$ Brix $)$ were recorded in single spray (at 20 DAT).

\section{Ascorbic acid (mg $\left.100 \mathrm{~g}^{-1}\right)$}

Maximum ascorbic acid was observed in $\mathrm{Zn}_{4}$ (28.11 mg $\left.100 \mathrm{~g}^{-1}\right)$ followed by $\mathrm{Zn}_{3}(27.43 \mathrm{mg}$ $\left.100 \mathrm{~g}^{-1}\right), \mathrm{Zn}_{2}\left(24.98 \mathrm{mg} 100 \mathrm{~g}^{-1}\right), \mathrm{Zn}_{1}(22.33$ mg $\left.100 \mathrm{~g}^{-1}\right)$ and $\mathrm{Zn}_{0}\left(19.17 \mathrm{mg} 100 \mathrm{~g}^{-1}\right)$ but $\mathrm{Zn}_{4}\left(\mathrm{ZnSo}_{4} 200 \mathrm{ppm}\right)$ was statistically at par with $\mathrm{Zn}_{3}\left(\mathrm{ZnSo}_{4} 150 \mathrm{ppm}\right)$. The result for number of sprays showed that maximum ascorbic acid (26.56 mg $\left.100 \mathrm{~g}^{-1}\right)$ was observed in three sprays (at 20, 40 and 60 DAT). Whereas, minimum ascorbic acid (22.04 $\mathrm{mg}$ $100 \mathrm{~g}^{-1}$ ) was recorded in single spray (at 20 DAT) (Fig. 1).

\section{Total sugars (\%)}

Maximum total sugar content in fruits was observed in $\mathrm{Zn}_{4}(4.72 \%)$ followed by $\mathrm{Zn}_{3}$ (4.69\%), $\mathrm{Zn}_{2}(4.31 \%), \mathrm{Zn}_{1}(3.81 \%)$ and $\mathrm{Zn}_{0}$ $(2.97 \%)$ but $\mathrm{Zn}_{4}\left(\mathrm{ZnSo}_{4} 200\right.$ ppm) was statistically at par with $\mathrm{Zn}_{3}\left(\mathrm{ZnSo}_{4} 150 \mathrm{ppm}\right)$. The result showed that the maximum total sugar $(4.55 \%)$ was observed in three sprays (at 20, 40 and 60 DAT). Whereas, minimum total sugar $(3.53 \%)$ was recorded in single spray (at 20 DAT) (Fig. 2).

\section{Moisture content in fruits (\%)}

The results showed that total foliar spray of different concentration of zinc sulphate on tomato had non-significant effect on moisture content. Number of sprays further showed that number of foliar sprays had non-significant effect on moisture content.

\section{Effect of foliar application of zinc sulphate on quality attributes}

Zinc sulphate treatments significantly influenced the quality characters of tomato fruits measured in terms of total soluble solids, ascorbic acid, total sugar and moisture content in fruits. Foliar spray of $200 \mathrm{ppm}$ concentration of zinc sulphate significantly increased the quality parameters but was statistically at par with $150 \mathrm{ppm}$ zinc sulphate. Importance of zinc in maintaining the integrity of bio membrane viz., pericarp in chilli was studied by Das (2007). Zinc protects the membrane lipid and proteins against oxidative damage.

Bhatt et al., (2004) studied the effect of foliar application of micronutrients on quality attributes of tomato. Results revealed that foliar application of zinc sulphate at $100 \mathrm{ppm}$ increased the acidity $(0.97 \%)$, total soluble solids $(4.96 \%)$ and ascorbic acid contents (29.11 mg /100g) compared to control.

Narayanamma et al., (2009) confirmed the similar trend with the foliar application of micronutrients on quality parameters of bitter gourd. They found highest vitamin $\mathrm{C}$ content and total sugar with the application of zinc sulphate@0.01\% concentration.

Patil et al., (2010) also obtained similar result while working with effect of foliar application of micronutrients on quality of tomato. Results revealed that, application of $\mathrm{Fe}+\mathrm{Zn}$ each at $100 \mathrm{ppm}$ along with boron at $50 \mathrm{ppm}$ significantly increased total soluble solids $\left(3.82{ }^{0}\right.$ Brix $)$ and decreased acidity $(0.27 \%)$ (Table 3 and 4). 
Table.1 Details of the treatments with their symbols

\begin{tabular}{|c|c|c|c|}
\hline $\begin{array}{l}\text { Concentration of Zinc } \\
\text { Sulphate (ppm) }\end{array}$ & $\begin{array}{c}\text { Number of } \\
\text { spray }\end{array}$ & $\begin{array}{c}\text { Time of } \\
\text { spray (DAT) }\end{array}$ & $\begin{array}{c}\text { Treatment } \\
\text { code }\end{array}$ \\
\hline 0 & 1 & 20 & $\mathrm{~T}_{1}$ \\
\hline $\mathbf{0}$ & 2 & 20,40 & $\mathbf{T}_{2}$ \\
\hline 0 & 3 & $20,40,60$ & $\mathbf{T}_{3}$ \\
\hline 50 & 1 & 20 & $\mathbf{T}_{4}$ \\
\hline 50 & 2 & 20,40 & $T_{5}$ \\
\hline 50 & 3 & $20,40,60$ & $T_{6}$ \\
\hline 100 & 1 & 20 & $\mathbf{T}_{7}$ \\
\hline 100 & 2 & 20,40 & $\mathbf{T}_{8}$ \\
\hline 100 & 3 & $20,40,60$ & $T_{9}$ \\
\hline 150 & 1 & 20 & $T_{10}$ \\
\hline 150 & 2 & 20,40 & $\mathbf{T}_{11}$ \\
\hline 150 & 3 & $20,40,60$ & $T_{12}$ \\
\hline 200 & 1 & 20 & $T_{13}$ \\
\hline 200 & 2 & 20,40 & $T_{14}$ \\
\hline 200 & 3 & $20,40,60$ & $T_{15}$ \\
\hline
\end{tabular}

Table.2 Chronology of crop raising during different phases

\begin{tabular}{|c|c|c|c|}
\hline $\begin{array}{c}\text { S. } \\
\text { NO. }\end{array}$ & Operations & Date & Remarks \\
\hline $\mathbf{1 .}$ & Field preparation & 20.11 .2016 & Manually \\
\hline $\mathbf{2 .}$ & Layout of experimental field & 22.11 .2016 & Manually \\
\hline $\mathbf{3 .}$ & Seed Sowing & 01.12 .2016 & In nursery \\
\hline $\mathbf{4 .}$ & $\begin{array}{c}\text { Application of manures and } \\
\text { fertilizers }\end{array}$ & 14.01 .2017 & Basal application manually \\
\hline $\mathbf{5 .}$ & Pre-transplanting irrigation & 18.01 .2017 & Drip-irrigation \\
\hline $\mathbf{6 .}$ & Transplanting & 19.01 .2017 & Manually by hand \\
\hline $\mathbf{7 .}$ & $\begin{array}{c}\text { Foliar application of zinc } \\
\text { sulphate per treatment }\end{array}$ & 09.02 .2017 & Three sprays by sprayer \\
\hline $\mathbf{8 .}$ & Hoeing and weeding & 27.03 .2017 & \\
\hline & & 20.02 .2017 & Manually I \\
\hline $\mathbf{9 .}$ & Staking & 07.03 .2017 & Manually II \\
\hline $\mathbf{1 0 .}$ & Plant protection operation & 27.03 .2017 & Manually \\
\hline $\mathbf{1 1 .}$ & Number of picking & 16.03 .2017 & Malathion 50 EC @ 0.05\% \\
& 1. & $12.04 .2017-13.04 .2017$ & $\begin{array}{c}\text { Fully mature fruits } \\
\text { at red colour break } \\
\text { stage were manually } \\
\text { harvested periodically. }\end{array}$ \\
\hline & 2. & $19.04 .2017-21.04 .2017$ & \\
\hline $\mathbf{1 2 .}$ & Total number of picking & $27.04 .2017-03.05 .2017$ & \\
\hline
\end{tabular}


Table.3 Effect of foliar spray of zinc sulphate on total soluble solids ( ${ }^{0} \mathrm{Brix}$ ) and ascorbic acid (mg $100 \mathrm{~g}^{-1}$ ) of tomato

\begin{tabular}{|c|c|c|}
\hline Treatments & $\begin{array}{c}\text { TSS } \\
\left({ }^{0} \text { Brix }\right)\end{array}$ & 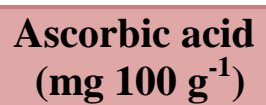 \\
\hline \multicolumn{3}{|c|}{ Zinc sulphate levels (ppm) } \\
\hline $\mathrm{Zn}_{0} \quad 0 \mathrm{ppm}$ & 4.17 & 19.17 \\
\hline $\mathrm{Zn}_{1} \quad 50 \mathrm{ppm}$ & 4.74 & 22.33 \\
\hline $\mathrm{Zn}_{2} \quad 100 \mathrm{ppm}$ & 5.18 & 24.98 \\
\hline $\mathrm{Zn}_{3} \quad 150 \mathrm{ppm}$ & 5.54 & 27.43 \\
\hline $\mathrm{Zn}_{4} \quad 200 \mathrm{ppm}$ & 5.66 & 28.11 \\
\hline SEm+ & 0.114 & 0.759 \\
\hline $\mathrm{CD}(\mathrm{P}=\mathbf{0 . 0 5})$ & 0.330 & 2.192 \\
\hline \multicolumn{3}{|c|}{ Number of spray at (DAT) } \\
\hline $\mathrm{S}_{1} \quad 20$ & 4.25 & 22.04 \\
\hline $\mathrm{S}_{2} \quad 20,40$ & 5.12 & 24.62 \\
\hline$S_{3} \quad 20,40,60$ & 5.81 & 26.56 \\
\hline SEm+ & 0.09 & 0.59 \\
\hline $\mathrm{CD}(\mathrm{P}=\mathbf{0 . 0 5})$ & 0.26 & 1.70 \\
\hline
\end{tabular}

Table.4 Effect of foliar spray of zinc sulphate on total sugars (\%) and moisture content in fruits (\%) of tomato

\begin{tabular}{|c|c|c|}
\hline Treatments & Total sugars (\%) & Moisture content in fruits (\%) \\
\hline \multicolumn{3}{|c|}{ Zinc sulphate levels (ppm) } \\
\hline $\mathrm{Zn}_{0} \quad 0 \mathrm{ppm}$ & 2.97 & 93.68 \\
\hline $\mathrm{Zn}_{1} \quad 50 \mathrm{ppm}$ & 3.81 & 94.46 \\
\hline $\mathrm{Zn}_{2} \quad 100 \mathrm{ppm}$ & 4.31 & 94.84 \\
\hline $\mathrm{Zn}_{3} \quad 150 \mathrm{ppm}$ & 4.69 & 95.40 \\
\hline $\mathrm{Zn}_{4} \quad 200 \mathrm{ppm}$ & 4.72 & 95.57 \\
\hline SEm+ & 0.126 & NS \\
\hline $\mathrm{CD}(\mathrm{P}=\mathbf{0 . 0 5})$ & 0.364 & NS \\
\hline \multicolumn{3}{|c|}{ Number of spray at (DAT) } \\
\hline $\mathrm{S}_{1} \quad 20$ & 3.53 & 93.63 \\
\hline $\mathrm{S}_{2} \quad 20,40$ & 4.22 & 95.30 \\
\hline$S_{3} \quad 20,40,60$ & 4.55 & 95.43 \\
\hline SEm+ & 0.10 & NS \\
\hline $\mathrm{CD}(\mathrm{P}=\mathbf{0 . 0 5})$ & 0.28 & NS \\
\hline
\end{tabular}


Fig.1 Effect of zinc sulphate on Ascorbic acid (mg 100 g-1) of tomato

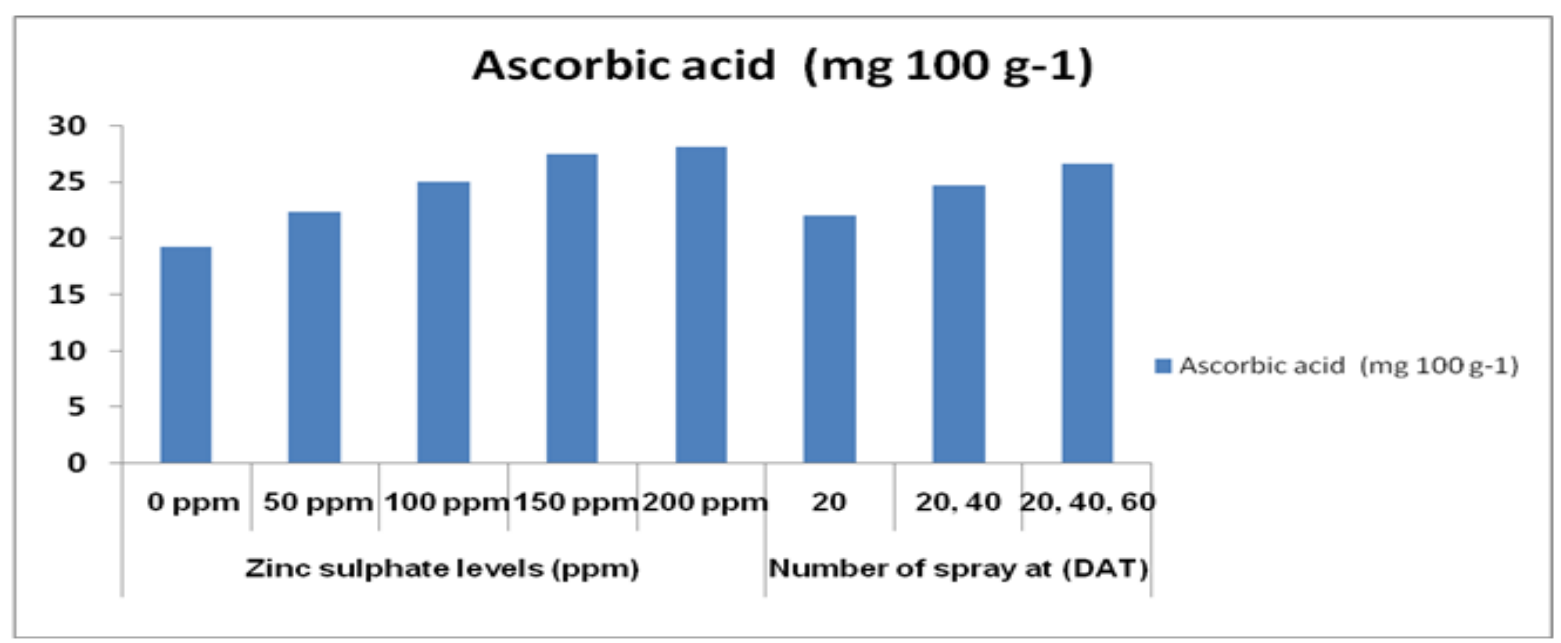

Fig.2 Effect of zinc sulphate on total sugar \% of tomato

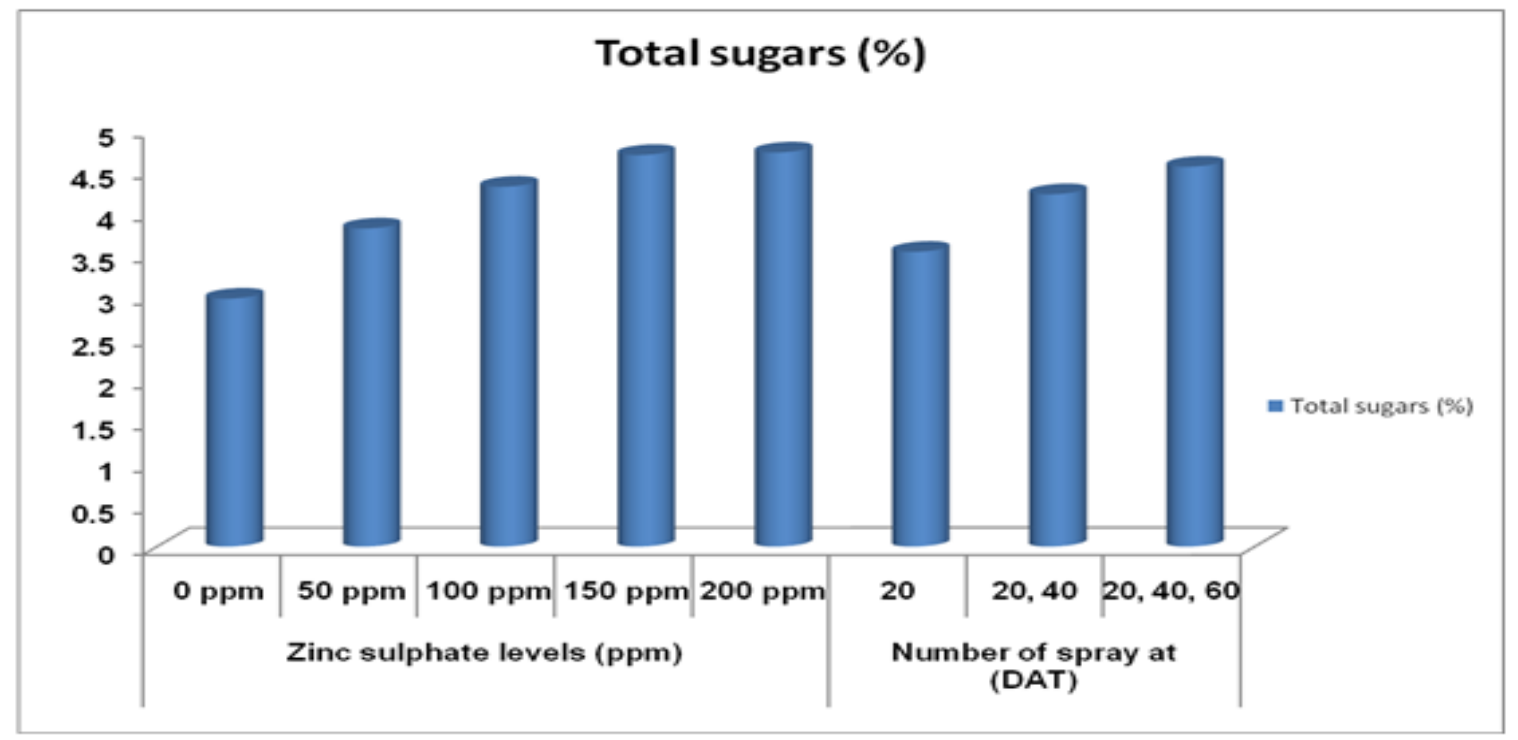

ZnSo4@200 ppm zinc sulphate recorded maximum total soluble solids (5.66 ${ }^{0}$ Brix) as compared to total soluble solids of fruit in control (4.17 ${ }^{0}$ Brix). Maximum total soluble solids $\left(5.81{ }^{0}\right.$ Brix $)$ was observed in three sprays (at 20, 40 and 60 DAT) whereas, minimum total soluble solids $\left(4.25{ }^{0} \mathrm{Brix}\right)$ was recorded in one spray (at 20 DAT). ZnSo4 @ $200 \mathrm{ppm}$ zinc sulphate recorded maximum $\left(28.11 \mathrm{mg} 100 \mathrm{~g}^{-1}\right)$ ascorbic acid was recorded as compared to $\left(19.17 \mathrm{mg} 100 \mathrm{~g} \mathrm{~g}^{-1}\right)$ control. Maximum ascorbic acid (26.56 mg $\left.100 \mathrm{~g}^{-1}\right)$ was observed in three sprays (at 20, 40 and 60 DAT) whereas, minimum ascorbic acid was (22.04 mg $100 \mathrm{~g}^{-1}$ ) recorded in one spray (at 20 DAT). A maximum (4.72\%)) total sugar was recorded in $\mathrm{ZnSo}_{4} 200 \mathrm{ppm}$ as compared to $(2.97 \%)$ in control.

Maximum total sugar $(4.55 \%)$ was observed in three sprays (at 20,40 and 60 DAT) whereas; minimum total sugar (3.53\%) was recorded in one spray (at 20 DAT). Foliar spray of different concentration of zinc 
sulphate and number of sprays on tomato had non- significant effect on moisture content $(\%)$.

It may be concluded that the application of zinc sulphate as foliar spray is beneficial in improving fruit quality of tomato cv. Arka Rakshak in Bikaner under polyhouse condition. The most effective treatment in increasing the fruit quality of tomato under present experiment was foliar spray of zinc sulphate $200 \mathrm{ppm}$. The maximum benefit cost ratio of (2.98:1) was recorded under Zinc sulphate $200 \mathrm{ppm}$.

\section{References}

Anonymous, 2015-16. Indian horticulture data base, National Horticulture Board, Ministry of Agriculture, GOI, Guagaon Eds. Ministry, NC, Sing Brijendra and Ghardi, C.P. pp 14-15.

Benepal, P. S. 1967. Influence of micronutrients on growth and yield of potatoes. Amer. Potato J. 44 (10): 363 $-369$.

Bhatt, L.; Srivastava, B. K. and Singh, M. P., 2004. Studies on the effect of foliar application of micronutrients on growth, yield and economics of tomato. Prog. Hort., 36 (2): 331-334.

Das, D. K., 2007, Micronutrients: Their behaviour in soils and plants. Kalyani Publishers, New Delhi.

Ferrandon, M. and Chamel, A. R. 1988. Cuticular retention, foliar absorption and translocation of iron, manganese and zinc supplied in organic and inorganic form. J. Plant Nutr. $11: 247$ $-262$.
Fisher, R. A. 1950. Statical Methods for Research Workers. Oliver and Boyd Edinburgh, London.

Kannan, S. 1990. Role of foliar fertilization in plant nutrition, In: Crops as Enhancers of Nutrient Use (Baligar, V. C. and Duncan, R. R. eds.). Academic Press, San Diego. pp 313-348.

Narayanamma, M.; Radha Rani, K.; Lalitha Kameswari, P. and Reddy, R. V. S. K. 2009. Effect of foliar application of micronutrients on the yield components, yield and nutrient content of bitter gourd. Orissa J. Hort., $37(2): 1-5$.

Panse, and V. G. and Sukhatme, P. V. 1985. Statistical methods for agricultural workers. Indian Council of Agricultural Research, New Delhi.

Patil. V. K., Yadlod, S. S., Kadam, A. S. and Narsude, P. B., 2010. Effect of foliar application of micronutrients on yield and quality of tomato (Lycopersicon esculentum Mill.) cv. Phule Raja. Asian J. Hort., 2 (4): 458-460.

Ranganathan, D. S. and Perumal, R. 1995. Effect of micronutrients with/without organics and biofertilizers on growth and development of tomato in Inceptisol and Alfisol. South Indian Hort., 43 (3 \& 4) : 89-92.

Thompson, H. C. and Kelly, W. C. 1957. Vegetable Crops. $5^{\text {th }}$ Edn., McGraw Hill Book Company. New York pp. 471-500.

Wallace, T. 1957. Trace elements in plant nutrition with special reference to crops. J. of the Royal Society of Arts, 105 (5004): 515-534.

\section{How to cite this article:}

Vimal Nagar, Susheel Kumar, Upendar Kumar Bagri, Raja Ram Bunker and Himani Rana. 2021. Assessment of Effect of Foliar Spray of Zinc Sulphate on Fruit Quality of Tomato under Polyhouse. Int.J.Curr.Microbiol.App.Sci. 10(02): 2376-2383. doi: https://doi.org/10.20546/ijcmas.2021.1002.282 